\title{
GENTE DE GUERRA: NOVAS PERSPECTIVAS SOBRE O BRASIL HOLANDÊS
}

\section{Mariana Françozo*}

Universidade de Leiden Leiden - Holanda

Resenha do livro: MIRANDA, Bruno Romero Ferreira. Gente de guerra. Origem, cotidiano e resistência dos soldados do exército da Companhia das Índias Ocidentais no Brasil (1630-1654). Recife: Ed. UFPE, 2014.

Na introdução a Gente de guerra, o historiador Ronaldo Vainfas acertadamente descreve Bruno Miranda como parte de uma nova geração de historiadores que, munida do conhecimento da língua holandesa e debruçada sobre vasta e variada documentação primária, vem repensando e expandindo a tradicional historiografia sobre o domínio holandês no Brasil no século XVII. Esse livro, fruto de tese de doutoramento em História defendida na Universidade de Leiden, em 2011, constitui - pela primeira vez na historiografia nacional e internacional sobre o Brasil holandês - uma obra dedicada exclusivamente à história "de alguns dos muitos personagens anônimos que

Doutora em Ciências Sociais pela Unicamp. Professora na Faculdade de Arqueologia, Universidade de Leiden, Países Baixos. Email: m.francozo@arch.leidenuniv.nl 
participaram da conquista e manutenção do Brasil" (p. 30): os soldados da Companhia das Índias Ocidentais (WIC). Cabe adicionar: personagens que participaram também da perda do Brasil holandês e das derrotas da WIC na América do Sul. Afinal, como mostra Miranda, a má condição geral das tropas foi decisiva para o destino frustrado das intenções militares e políticas dos holandeses no Brasil.

Na introdução, um pouco seca - pois não há floreios - e bastante direta - porque é descritiva, como o livro todo -, Miranda introduz seus personagens principais, bem como a estrutura da obra, centrada em perguntas sobre quem era e como (sobre)vivia a soldadesca da Companhia das Índias Ocidentais no Brasil. Ao longo dos capítulos, encontram-se as motivações e os diálogos teóricos que impulsionaram o autor a formular suas questões. A começar, com efeito, com a dúvida lançada no início da década de 1980 pelos historiadores Pieter Emmer e Ernst van den Boogaart sobre a própria possibilidade de escrever uma história dos soldados da WIC (p. 44). Em um livro bem escrito e bem composto, o leitor encontra numerosas descrições de momentos significativos do cotidiano dessa gente: os motivos para se alistarem na Companhia, as circunstâncias da viagem atlântica, as dificuldades da vida diária no Brasil, o trabalho, as lutas, as doenças, a revolta e, finalmente, a volta - quando possível - para a Europa.

Ainda que a possibilidade de reconstruir integralmente o cotidiano desses soldados seja limitada pela incompletude das fontes - drama e circunstância de todo historiador -, Miranda consegue esboçar com fidelidade um quadro diversificado de pessoas, motivações, escolhas e trajetórias que, em conjunto, fazem sentido. Isso só foi possível porque o autor mergulhou sem medo nos acervos documentais dos Países Baixos - muitos dos quais já lidos e analisados anteriormente por célebres nomes da historiografia do Brasil holandês, como José Antônio Gonsalves de Mello, Charles Boxer, Evaldo Cabral de Mello e o próprio Ronaldo Vainfas. Foram consultados velhos conhecidos, como os arquivos da Velha Companhia das Índias Ocidentais (OWIC) e os arquivos dos Estados Gerais (ambos no Arquivo Nacional de Haia), que provaram neste livro ser fonte ainda rica de novos dados, quando lidos sob nova perspectiva. $\mathrm{O}$ autor expande o acervo documental ao investir também nos registros notariais das cidades de Amsterdã e Roterdã para cruzar dados e, assim, estabelecer redes e relações entre esses soldados e a vida diária na colônia e nos Países Baixos. Outra fonte central foram os vários relatos dos soldados que escreveram sobre suas experiências na WIC, alguns dos quais aparecem repetidamente no livro (como Stephen Carl e Peter Hansen), dada a riqueza de sua narrativa. As imagens aparecem apenas eventualmente como 
ilustrações ou fontes que confirmam hipóteses - com destaque, nesse sentido, para o problema da indumentária dos soldados expresso em gravura que registra soldados roubando as vestes de inimigos mortos ou feridos (p. 193).

Nos capítulos 1 e 2 do livro, que tratam de dados demográficos e do engajamento na companhia, os achados sobre os soldados do Brasil holandês são constantemente confrontados com dados de mesma natureza sobre os soldados da Companhia das Índias Ocidentais (VOC), com inspiração clara no trabalho de Roelof van Gelder sobre a "aventura" asiática dos soldados da VOC. ${ }^{1}$ Dessa forma, e para compensar as fontes inconclusivas, Miranda compara, contrasta e confirma suas hipóteses com respaldo em sólida literatura sobre os militares europeus na Ásia e África, bem como a soldadesca europeia no período moderno. Da mesma forma, no capítulo 4, ao tratar das doenças que afligiam as tropas no Brasil, Miranda esboça uma comparação com os casos de militares europeus na África e Ásia (p. 231-240). Assim, apesar de não ir a fundo na comparação, o autor sugere a possibilidade de ampliar o escopo dos estudos do Brasil holandês, levando-o a um cenário de história atlântica - como alguns pesquisadores já vêm fazendo - e, quando cabível, mesmo de história global. O livro, assim, afasta-se de uma "historiografia pernambucana", na qual o prefaciador do livro parece querer enquadrar Bruno Miranda (p. 15), e aproxima-se de uma historiografia comparativa, que analisa as origens e o funcionamento dos impérios coloniais europeus em perspectiva transnacional.

Gente de guerra traz pelo menos três importantes proposições sobre os "personagens anônimos" cujas histórias pretende recuperar. Em primeiro lugar, mostra que a maioria dos soldados da WIC - companhia holandesa - não era holandesa, mas tinha origem geográfica variada, com numerosa presença de homens vindos dos Estados alemães, seguidos por aqueles dos Países Baixos espanhóis, Inglaterra, França, Escandinávia e Escócia (p. 56). Em segundo lugar, o livro contribui para desmistificar a ideia de que esses soldados eram gente "da pior fama", pobretões em busca de riqueza rápida, homens de má índole e pouca formação. Ao contrário, Bruno Miranda revela a diversidade das origens sociais desses soldados, e mostra, com rigor, como muitos deles só conseguiram se alistar na WIC e garantir lugar no exército no Brasil justamente porque sabiam algum ofício que poderia ser útil durante as lutas ou depois delas. Finalmente, o livro indica o papel fundamen-

\footnotetext{
1 VAN GELDER, Roelof. Het Oost-Indische Avontuur: Duitsers in dienst van de VOC (1600-1800). Nijmegen: SUN, 1997, 335 p.
} 
tal da condição de vida desses soldados na derrocada dos holandeses no Brasil. Na segunda parte do livro, Miranda mostra como as tropas eram, via de regra, mal alimentadas, doentes, mal pagas e em geral maltratadas tanto por seus superiores no Brasil quanto pelas autoridades da WIC na Holanda, que não respondiam às suas demandas com a rapidez e a eficiência necessárias. Sem vitimizá-los, o autor conta as estratégias de sobrevivência empregadas, com maior ou menor grau de sucesso, pelos soldados da WIC. Assim, se alguns desses soldados escolheram desertar, passar ao lado inimigo, ou amotinar-se (capítulo 6), as origens de seu descontentamento residiam na tentativa da WIC, operando muitas vezes perto de decretar falência, de gerar lucro a qualquer custo (ou, em bom holandês: voor een dubbeltje op de eerste rang zitten - por alguns centavos, sentar-se no melhor lugar). Em tais condições de miséria, combater o inimigo era uma missão quase impossível e, por isso, o malogro da WIC no Brasil tem que ser compreendido também pela lente das experiências sofridas desses homens.

Se há críticas ao livro, elas recaem em certa falta de posicionamento mais claro do autor em relação à literatura brasileira e estrangeira sobre o Brasil holandês. Um pouco por modéstia, Miranda parece querer sugerir que o livro trata de um aspecto até agora negligenciado dessa história - as trajetórias e o cotidiano dos soldados da WIC. Em relação a esse aspecto, o livro de fato traz uma contribuição clara e o autor não se furta a indicar, quando cabível, pequenos erros ou grandes deslizes da literatura da área. Porém, mais do que "um tijolinho a mais" ou uma narrativa a mais, Gente de guerra ajuda a situar o próprio Brasil holandês em outro plano de análise. Muitas vezes tratado como evento episódico tanto na historiografia sobre o Brasil Colônia quanto na bibliografia holandesa sobre a expansão ultramarina, as três décadas em que a WIC ocupou parte da costa nordeste da América portuguesa tiveram impacto militar, econômico, político, social e cultural dos dois lados do oceano Atlântico, bem como na política local nos Países Baixos. Menos que um episódio histórico interessante, o período do Brasil holandês fez parte de um sistema atlântico de relações (desiguais) de poder que marcaram a história de pelo menos três continentes interligados ao mesmo tempo que ajudou a construir esse sistema. Menos do que apenas recontar a história dos soldados da WIC, Gente de guerra ajuda a lançar nova luz sobre as redes de relações que compuseram o emaranhado do Brasil holandês. Por isso, deverá ser lido por todos aqueles interessados no período moderno, em história atlântica e na (nova) história militar.

Recebido: 21/9/2015 - Aprovado: 31/3/2016 